\title{
Autonomous Decentralized Control of Supply and Demand by Inverter Based Distributed Generations in Isolated Microgrid
}

\author{
Akira Shiki Student Member (University of Tokyo) \\ Akihiko Yokoyama Member (University of Tokyo) \\ Jyunpei Baba Member (University of Tokyo) \\ Tomihiro Takano Member (Mitsubishi Electric Corporation) \\ Takahiro Gouda Member (Kyushu University) \\ Yoshio Izui Senior Member (Mitsubishi Electric Corporation)
}

Keywords: microgrid, distributed generation, autonomous decentralized control, supply and demand control, inverter, storage battery

\section{Introduction}

Recently, because of the environmental burden mitigation, energy conservations, energy security, and cost reductions, distributed generations are attracting our strong attention. These distributed generations (DGs) have been already installed to the distribution system, and much more DGs will be expected to be connected in the future. On the other hand, a new concept called "Microgrid" which is a small power supply network consisting of only DGs was proposed and some prototype projects are ongoing in Japan.

The purpose of this paper is to develop the three-phase instantaneous valued digital simulator of microgrid consisting of a lot of inverter based DGs and to develop a new supply and demand control method in the isolated microgrid.

\section{Digital Simulator of Microgrid}

Here, the microgrid is modeled using MATLAB/SIMULINK. We develop models of three-phase instantaneous valued inverter type CVCF generator, PQ specified generator, PV specified generator, PQ specified load as storage battery, photovoltaic generation, fuel cell and inverter load respectively.

\section{Supply and Demand Control}

We propose a new autonomous decentralized control method of supply and demand in the isolated microgrid where storage batteries, fuel cells, photovoltaic generations and loads are connected. It is proposed here that the system frequency is used as a means for information transmission to control DG output. By changing the frequency of the storage battery due to unbalance of supply and demand, all inverter based DGs detect the frequency fluctuation and change their own outputs.

Fig. 2 shows results of the simulation. In Fig. 2 the required capacity of the storage battery is 32.14 [kW]. It is seen from Fig. 3 that the fuel cell can follow both the short-term and middle-term load fluctuation. Here, the response rate of the fuel cell is assumed to be high, but the present fuel cell has a problem in the rate of output change. Therefore it seems that much more response time is required for the practical use.

\section{Frequency Control}

Here, a new frequency control method in autonomous decentralized control of supply and demand is proposed. Though the frequency is used to transmit the information on the supply and
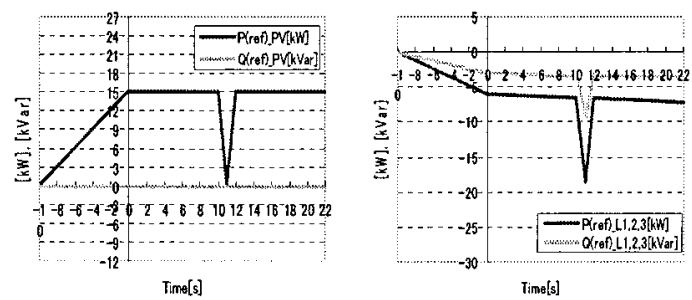

Fig. 1. PQ reference of photovoltaic generator and load No.1, 2, 3
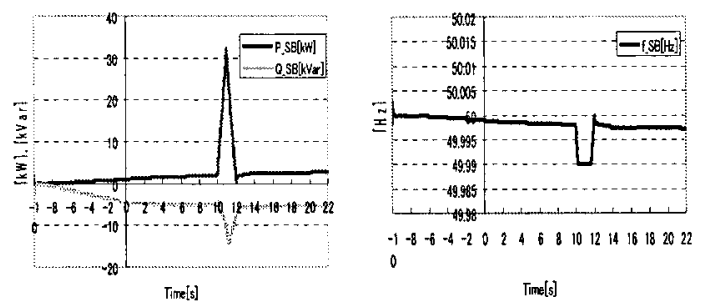

Fig. 2. PQ output and frequency of the storage battery
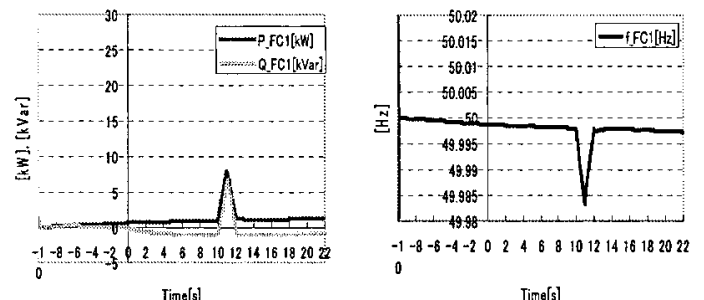

Fig. 3. PQ output and frequency of the fuel cell No.1

demand unbalance to DGs, after the frequency plays the role, the frequency finally has to return to a standard value. To return the frequency to the standard value, the characteristic curve (P-f curve) of the fuel cell is shifted in parallel. This control is carried out corresponding to the fluctuation of the load. The simulation shows that the frequency can be controlled well and the effectiveness of the frequency control system has been made clear. 


\title{
単独マイクログリッドにおけるインバータを用いた 分散型電源群による自律分散型需給制御
}

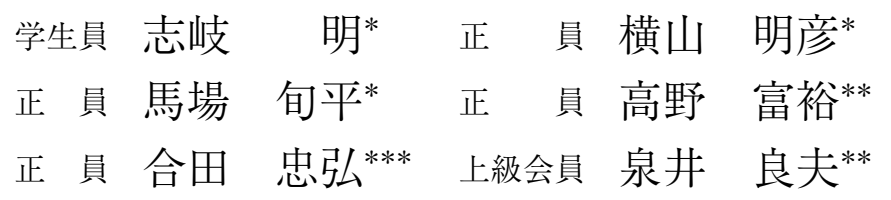

\section{Autonomous Decentralized Control of Supply and Demand by Inverter Based Distributed Generations in Isolated Microgrid}

\author{
Akira Shiki*, Student Member, Akihiko Yokoyama*, Member, Jyunpei Baba*, Member, \\ Tomihiro Takano**, Member, Takahiro Gouda***, Member, Yoshio Izui**, Senior Member
}

Recently, because of the environmental burden mitigation, energy conservations, energy security, and cost reductions, distributed generations are attracting our strong attention. These distributed generations (DGs) have been already installed to the distribution system, and much more DGs will be expected to be connected in the future. On the other hand, a new concept called "Microgrid" which is a small power supply network consisting of only DGs was proposed and some prototype projects are ongoing in Japan.

The purpose of this paper is to develop the three-phase instantaneous valued digital simulator of microgrid consisting of a lot of inverter based DGs and to develop a supply and demand control method in isolated microgrid.

First, microgrid is modeled using MATLAB/SIMULINK. We develop models of three-phase instantaneous valued inverter type CVCF generator, PQ specified generator, PV specified generator, PQ specified load as storage battery, photovoltaic generation, fuel cell and inverter load respectively. Then we propose an autonomous decentralized control method of supply and demand in isolated microgrid where storage batteries, fuel cells, photovoltaic generations and loads are connected. It is proposed here that the system frequency is used as a means to control DG output. By changing the frequency of the storage battery due to unbalance of supply and demand, all inverter based DGs detect the frequency fluctuation and change their own outputs. Finally, a new frequency control method in autonomous decentralized control of supply and demand is proposed. Though the frequency is used to transmit the information on the supply and demand unbalance to DGs, after the frequency plays the role, the frequency finally has to return to a standard value. To return the frequency to the standard value, the characteristic curve of the fuel cell is shifted in parallel. This control is carried out corresponding to the fluctuation of the load. The simulation shows that the frequency can be controlled well and has been made clear the effectiveness of the frequency control system.

キーワード：マイクログリッド，分散型電源，自律分散制御，需給制御，変換器，蓄電池

Keywords: microgrid, distributed generation, autonomous decentralized control, supply and demand control, inverter, storage battery

\footnotetext{
* 東京大学大学院工学系研究科

于 113-8656 東京都文京区本郷 7-3-1

Department of Electrical Engineering, University of Tokyo

7-3-1, Hongo, Bunkyo-ku, Tokyo, 113-8656

** 三菱電機（株）

₹ 100-8310＼cjkstart東京都千代田区丸の内 2-2-3

Mitsubishi Electric Corporation

2-2-3, Marunouchi, Chiyoda-ku, Tokyo, 100-8310

*** 九州大学 電気電子システム工学部門

₹ 819-0395 福岡市西区元岡 744 番地

Kyushu University

744, Motooka, Nishi-ku, Fukuoka 819-0395
}

\section{1. はじめに}

近年，二酸化炭素をはじめとした環境負荷の低減，省工 ネルギー, エネルギーセキュリティの確保, コスト削減など 様々な観点から分散型電源と呼ばれる需要地近接かつ小容 量の電源が注目を集めている。これらの分散型電源は, 既 に配電系統に連系されてきており，今後，より大量に連系 されることが予想される ${ }^{(1)}$ 。

一方，この分散型電源によって小規模な電力供給システ ムを構築した「マイクログリッド」なる概念も提案されて 
いる。マイクログリッドとは，「複数の分散型電源，また は電力貯蔵設備がネットワーク内に形成され, 既存大規模 電力網と連系されるか，または独立して運用を行う機能を 有するものであり，需要家に対して電力の連続供給を行う ものである。と定義される。アメリカでは，ノーザン・パ ワー・システムズ社が “Microgrid”の名で商標登録してお

り，1980 年代以降この名称を使用している。

それぞれの分散型電源の特徵を相互補完する形で，分散 型電源を小規模ネットワーク化・システム化し, 電力系統に 対して影響をできる限り小さくし，また貢献することもで きる「良き市民」となるのが「マイクログリッド」である。 マイクログリッドには，以下の利点が期待されている。

・供給信頼度と電力品質の向上

・経済的なエネルギーの供給

・既存系統に対する，自然エネルギーによる出力変動の 低減化

・離島や辺地での電力供給

一方，課題も存在する。

・系統連系時の既存系統への影響

- 既存系統の安定運用に, いかに寄与するかといった運 転・制御に関する課題

- 単独運転時の系統が小さいが故に顕在化してくる各種 の問題（電力の需給制御，電圧・周波数の維持，高調波）

これらの課題に十分な考慮を払った上でマイクログリッ ドシステムを構築する必要がある。そこで, 本研究では, イ ンバータを用いた分散型電源を多数台接続可能なディジ夕 ルシミュレーション技術の確立と同時に, 将来の集合住宅に マイクログリッドを構築することとし，蓄電池システム，太 陽光発電システム, 燃料電池システムで構成されるマイクロ グリッドの単独運転時の自律分散型の需給制御方式の確立 を目的とする。なお，本研究では，MATLAB/SIMULINK を用いてディジタルシミュレータを構築している。

\section{2. マイクログリッドシミュレータのモデル(2)}

〈2・1〉基本波電圧源モデルＦig. 1 に本シミュレー ションで用いる三相瞬時值電圧源基本波モデルの考え方を 示す。PWM インバータから出力される電圧は矩形波とし て出力されるが，高調波を無視して解析する場合，基本波 を端子電圧として模擬することができる。すなわち，イン バータのスイッチング現象を無視し，インバータを用いた 分散型電源を系統から見た基本波電圧源として模擬する。 これを「基本波電圧源モデル」と呼ぶ。

〈2・2〉 蓄電池システム（CVCF）Ｆig.2に蓄電池シ ステムの回路図を示す。蓄電池 $(\mathrm{Vdc}$ 部) はインバータ, フィルタ，トランスを経て系統に連系される。

Fig. 3 にCVCF にて制御される蓄電池システムのモデル 構成と制御特性曲線を示す。電圧は一定（1 [p.u.]）に制御 される。蓄電池システムが自分自身の有効電力出力に応じ て作り出す周波数に関しては Fig. 3(b) に示す通り，出力一 周波数 (P-f) 特性曲線による制御を考える。出力が $0[\mathrm{~kW}]$

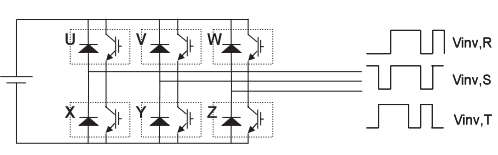

[Switching model]

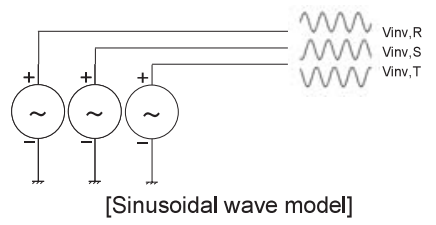

Fig. 1. Fundamental-wave voltage source model.

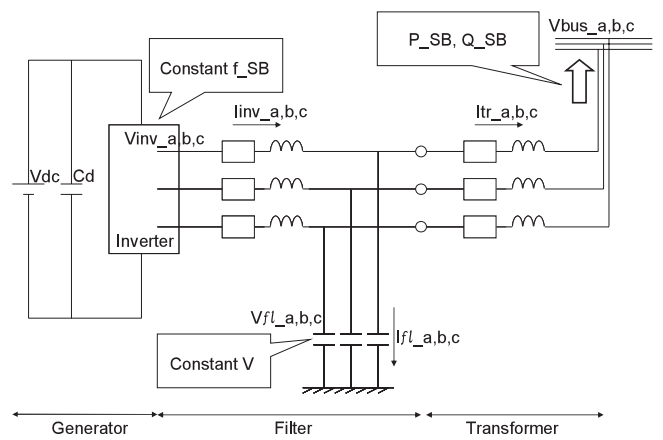

Fig. 2. Storage battery system.

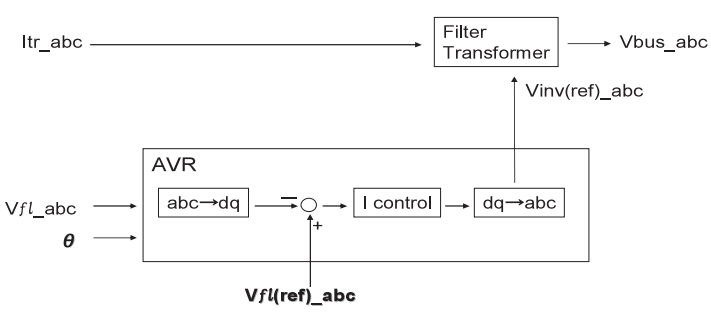

(a) Block diagram of storage battery system

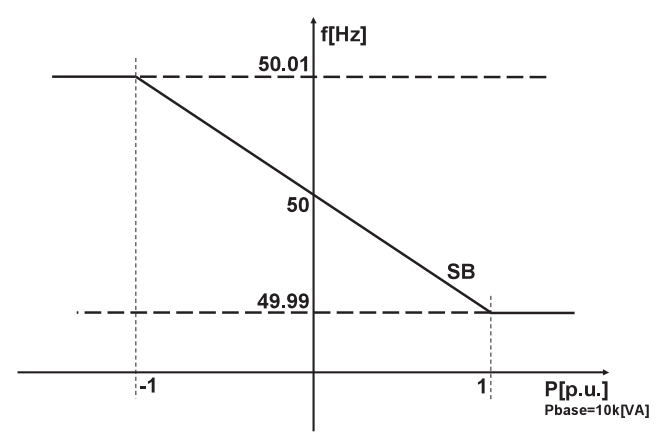

(b) P-f characteristic curve of storage battery system

Fig. 3. Block diagram and P-f characteristic curve of storage battery system.

のとき，周波数は $50[\mathrm{~Hz}]$ であり，特性曲線の傾きは負であ る。また本研究では, 周波数の変動幅は 49.99 50.01 [ Hz] とする。これは，実際には，マイクログリッドの総合的な 特性を考慮して決定されるべきものである。

〈2·3〉 太陽光発電システム（PQ指定） Fig.4に太陽 光発電システムの回路図を示す。太陽光発電 $(\mathrm{Vdc}$ 部) は インバータ，フィルタ，トランスを経て系統に連系される。

Fig. 5 にPQ 指定にて制御される太陽光発電システムの 


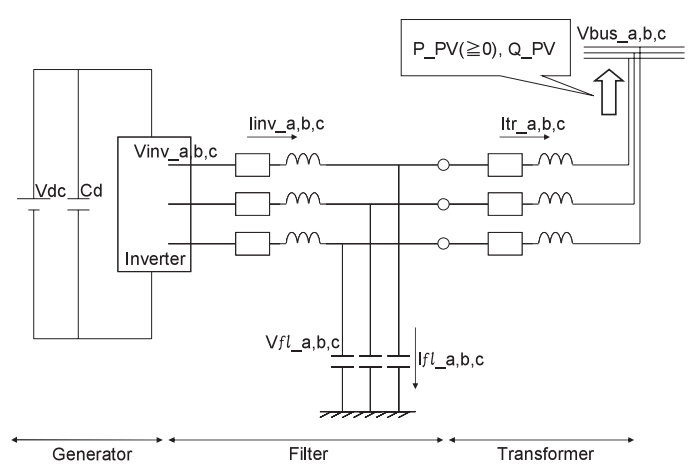

Fig. 4. Photovoltaic generation system.

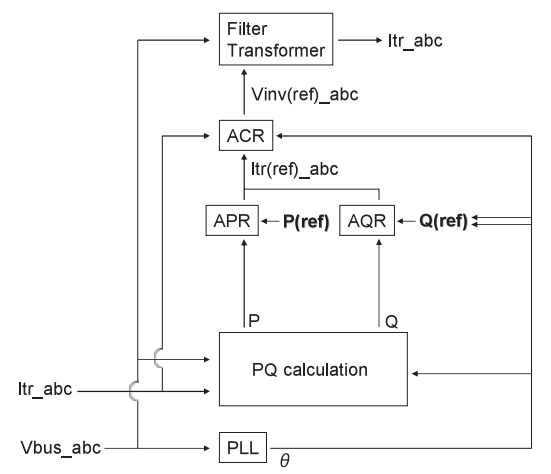

Fig. 5. Block diagram of photovoltaic generation system.

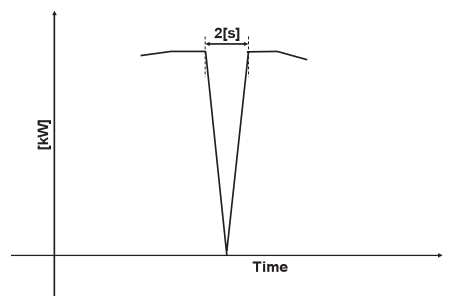

Fig. 6. Output change of photovoltaic generation (short term).

モデル構成を示す。

時間レンジの視点から分類した太陽光発電システムの出 力変動について以下に示す (3)(4)。

（1）短期 Fig.6に短期における雲などによる太陽 光発電の出力変動を示す。その時の出力から $0 \%$ まで落 する変動が任意の時間帯で生じ，その期間は $2[\mathrm{~s}]$ であると する。

（2）中期 中期における太陽光発電の出力变動はゼ ロとする。

（3） 長期 Fig.7 に長期における太陽光発電の出力 変動を示す。 12 時において $\mathrm{P}=15[\mathrm{~kW}]$ であり, 力率は常 に 1 であり $\mathrm{Q}=0[\mathrm{kVar}]$ 一定とする。

〈2.4〉 燃料電池システム（PV 指定） Fig. 8 に燃料電 池システムの回路図を示す。燃料電池 ( Vdc 部) はインバー タ, フィルタ,トランスを経て系統に連系される。なお，こ こでは燃料電池は小型の「固体高分子燃料電池 (PEFC)」を 想定している。

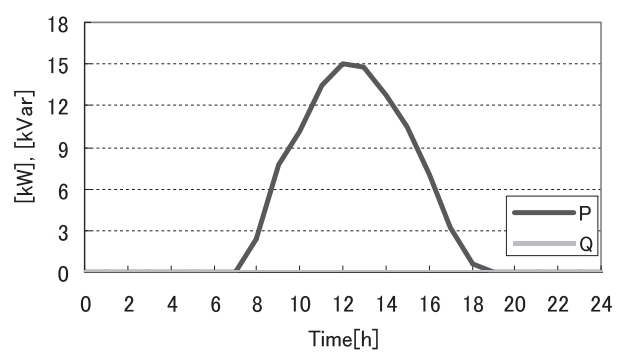

Fig. 7. Output change of photovoltaic generation (long term).

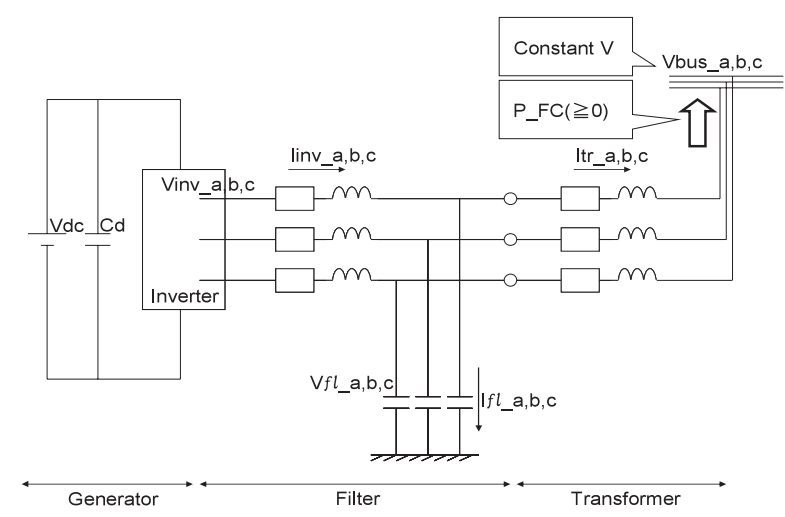

Fig. 8. Fuel cell system.

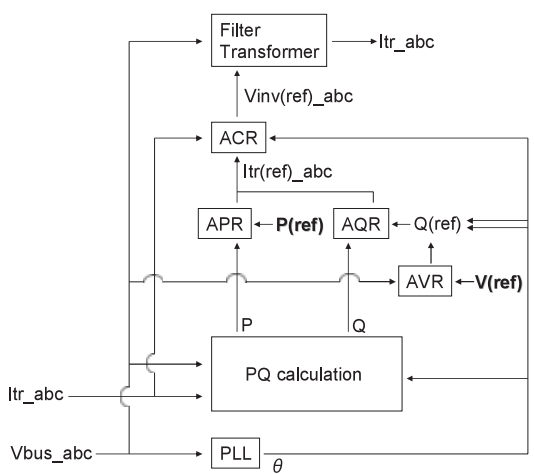

(a) Block diagram of fuel cell system

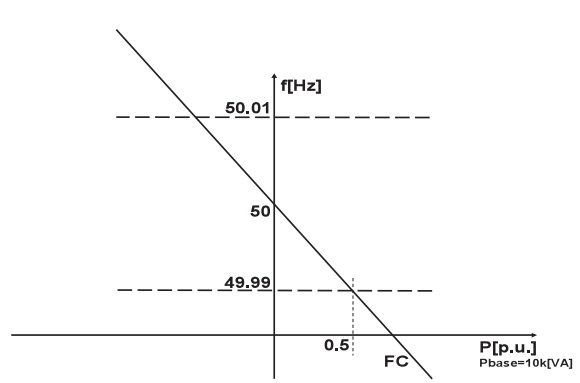

(b) P-f characteristic curve of fuel cell system

Fig. 9. Block diagram and P-f characteristic curve of fuel cell system.

Fig. 9 に燃料電池システムのモデル構成と制御特性曲線を 示す。燃料電池システムがPLLによる検出周波数に応じて 作り出す有効電力出力 $\mathrm{P}$ に関しては, Fig. 9(b) に示す出力一 周波数 (P-f) 特性曲線による制御を考える。ここでは, 周波 数が $50[\mathrm{~Hz}]$ のとき, 燃料電池が作り出す出力は $0[\mathrm{~kW}]$ と 


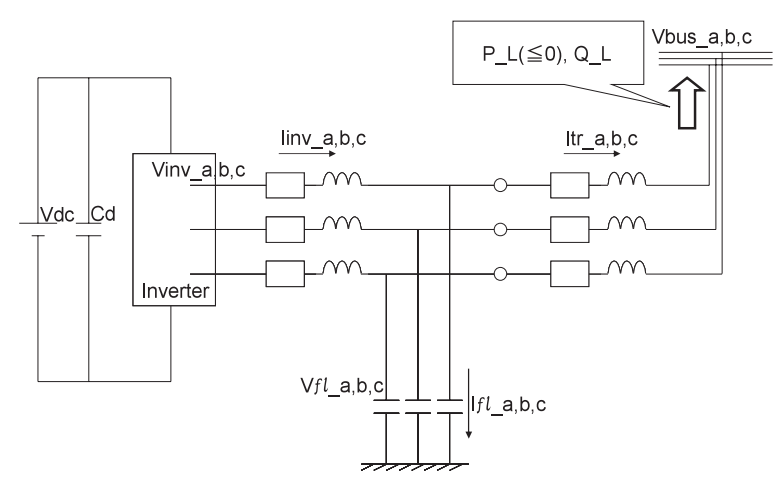

Fig. 10. Inverter type load.

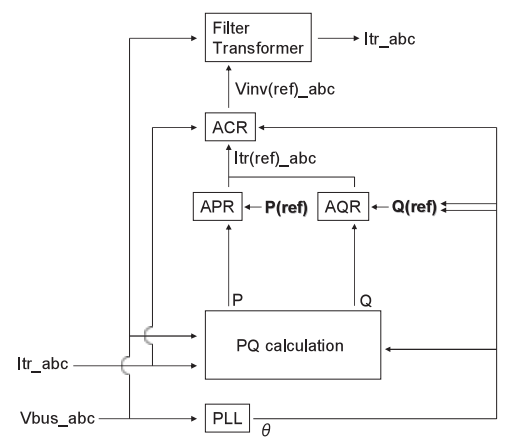

Fig. 11. Block diagram of inverter type load.

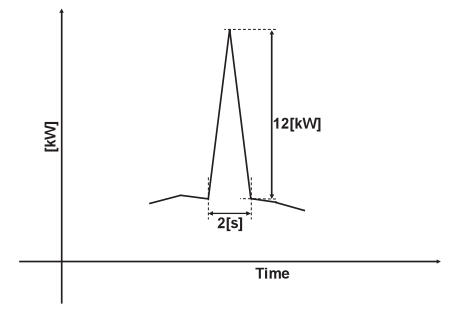

Fig. 12. Load change (short term).

しているが，この出力は分担している負荷量に依存するの で，必ずしも $0[\mathrm{~kW}]$ にする必要はない。特性曲線の傾きは 負であり，実際には蓄電池と同様に，マイクログリッドの 総合的な特性を考慮して決定することになる。

一方，Qに関しては AVRを組み込むことで端子電圧が 一定となるように，自動的に指令值を作り出す。

〈2.5〉 インバータ負荷 $(\mathbf{P Q}$ 指定） Fig. 10 にインバー 夕負荷の回路図を示す。

Fig. 11 にPQ 指定にて制御されるインバータ負荷のモデ ル構成を示す。

時間レンジの視点から分類した負荷変動について以下に 示す (5)。

（1）短期 Fig. 12 に, 短期における 10 軒当たりの負 荷変動を示す。一般家庭における急激な負荷変動は, 1 軒あ たり $0 \sim 4[\mathrm{~kW}]$ であるが，3 軒目までは単なる和となるが， 4 軒目以降は平準化され, 増加しないと仮定し, $12[\mathrm{~kW}]$ と なる。従って，最大の負荷変動を考え，力率一定で $12[\mathrm{~kW}]$ 上昇して，下落する変動が任意の時間带で生じ，その期間 は $2[\mathrm{~s}]$ であるとする。これは，ここで想定している団地等

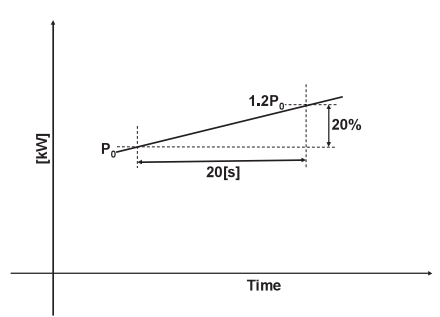

Fig. 13. Load change (middle term).

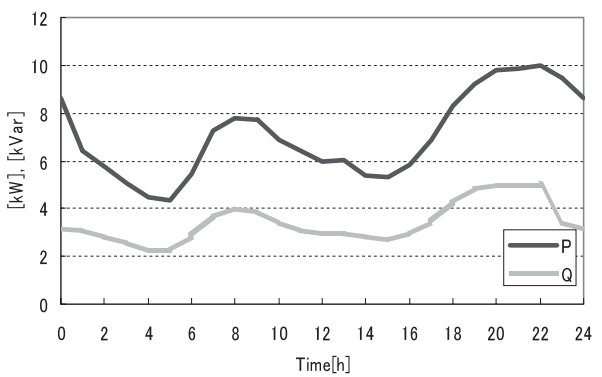

Fig. 14. Load change (long term).

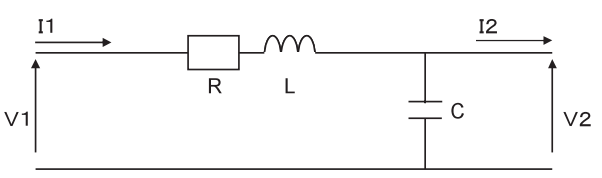

Fig. 15. Power distribution line.

の負荷実態より設定したものである。

（2）中期 Fig.13に中期における，10軒当たりの負 荷変動を示す。20 秒で $20 \%$ 変動するとする。

（3）長期 Fig, 14 に長期における，10 軒当たりの負 荷変動を示す。住宅地域負荷を想定したもので，12 時にお いて $\mathrm{P}=6[\mathrm{~kW}], \mathrm{Q}=3[\mathrm{kVar}]$ としている。

$\langle\mathbf{2} \cdot \mathbf{6}\rangle$ 配電線 Fig.15 に配電線の回路図を示す。 一般に，配電線のように短距離であるときは，考慮するの は直列の $\mathrm{R}$ と $\mathrm{L}$ のみであり, 並列の $\mathrm{C}$ は考慮しない。し かし，ここでは数值計算上，並列の $\mathrm{C}$ を考慮することにす る。ただし，その值は，Cの影響がなく，数值計算が不安 定にならないようにできるだけ小さくしている。

\section{3. 自律分散型需給制御}

$\langle\mathbf{3} \cdot \mathbf{1}\rangle$ 自律分散需給制御の概要 Fig. 16 に，自律分 散型制御に打ける全体イメージ図を示す。ここでは商用系 統から独立した状態のマイクログリッドを想定しており, 蓄電池, 太陽光発電, 燃料電池, 負荷が交流の自営線によっ て連系されている。

このマイクログリッド内において，分散型電源の出力制 御のための情報伝達手段として, 自営線の周波数を用いる ことを考える。一般に，周波数の変動幅は $50 \pm 0.2[\mathrm{~Hz}]$ に 抑える必要があり, 出来る限り変動幅を小さくする必要が ある。負荷変動による CVCF 制御の蓄電池の出力の変動に より，蓄電池が周波数を微小に変動させることで系統全体 に分布する分散型電源（ここでは燃料電池）に自営線の周 
波数という形で負荷変動の情報を送る。

ここで, 例えば, 負荷が増加する場合を考える。マイクロ グリッドは単独系統であるため，負荷が増加するのに伴っ て, CVCF 制御の蓄電池出力が増加する。すると, 蓄電池 は, 蓄電池 P-f 特性曲線（Fig. 3(b) 参照）に基づいて, 周 波数出力を下げる。蓄電池の周波数出力が下がることは, 自営線の周波数が下がることを意味する。次に, 燃料電池 システムは, 自営線の周波数を PLLを通して, 燃料電池シ ステム内で電圧を作り出すのに用いるために検出している が，自営線の周波数が下がると，この燃料電池周波数も下 がる。すると，燃料電池は，燃料電池特性曲線（Fig. 9(b) 参照）に基づいて, 燃料電池出力を増加させる。その結果, マイクログリッド内の需給のアンバランスは小さくなるの で, CVCF 制御の蓄電池出力は自動的に減少する。また, 負荷が減少する場合は，逆の制御となる。

これは, 負荷の変動に応じて,「(蓄電池出力 $)+($ 燃料電池 出力 $)=($ 負荷 $) 」$ とる周波数に収束する制御であり, 系統 全体の需給バランスをとりながら，分散型電源が自律的に 自身の出力を決定する「自律分散型需給制御方式」である。

また，制御の時間遅れは，端子電圧・電流の計測から特 性曲線に基づいた值の出力まで， $0.1[\mathrm{~s}]$ 程度としている。

$\langle\mathbf{3 \cdot 2 \rangle}$ 制御の評価 マイクログリッド制御の評価パ ラメータとして, 蓄電池容量を考える。 $\mathrm{kW}$ 容量と $\mathrm{kWh}$ 容 量の 2 種であるが, コスト面から考えて, 両者とも出来る限 り小さく抑えたい。さて, $\mathrm{kWh}$ 容量を考える場合, シミュ レーションを長時間行う必要がある。しかし，三相瞬時值 シミュレータはその特性上, 長時間シミュレーションを行 うには適していない。従って, 今回は, 評価パラメータと して，蓄電池 $\mathrm{kW}$ 容量のみを考慮することにする。

必要 $\mathrm{kW}$ 容量を求めるために, 蓄電池出力が出来る限り

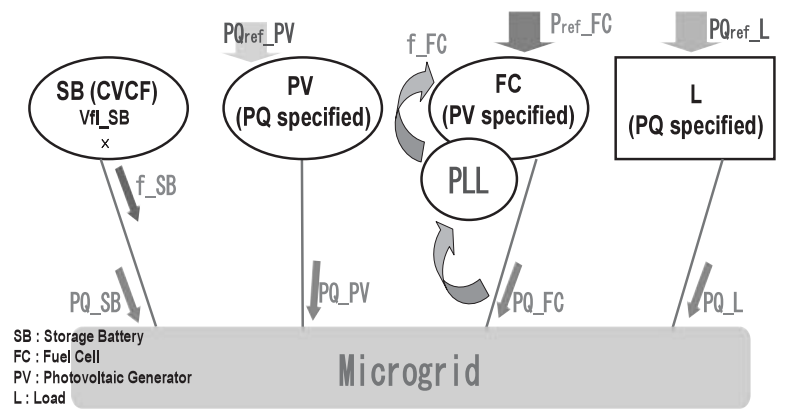

Fig. 16. Whole image of autonomous decentralized control of supply and demand.

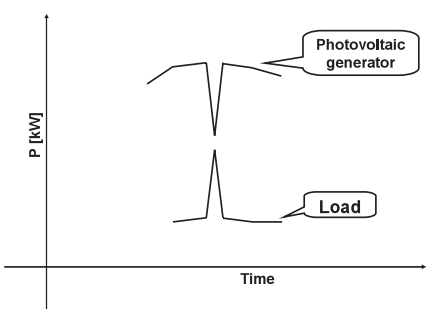

Fig. 17. Case of maximum storage battery output.
大きくなるような外部条件に対する系統の運用状況を考え， その条件の下でシミュレーションを行うことにする。それ は,「太陽光発電出力が急激に下落し」, かつ同時に「負荷 が急激に上昇する」条件（Fig. 17 参照）である。

\section{4. 特性曲線による需給制御シミュレーション結果}

〈4・1〉 特性曲線による制御の動作確認 蓄電池 1 台, 燃料電池 1 台, 負荷 1 台の簡単な系統を用いて P-f 特性曲 線による制御の動作確認を行う。

（1）条件 モデル系統を Fig. 18 に示す。配電線の長 さは $100 \mathrm{~m}$ で， $\mathrm{R}$ は $0.30[\Omega / \mathrm{m}], \mathrm{X}$ は $0.35[\Omega / \mathrm{m}]$ の值を用 いている。

Fig. 19(a) に負荷 1 の PQ 指令を, Fig. 19(b) に蓄電池と 燃料電池の出力一周波数 (P-f) 特性曲線を示す。なお, -3 0 [s] はシミュレータの立ち上げ期間である。

(2) 出力結果 Fig. 20 に出力結果を示す。

（3）考察 Fig. 20(a), (b) は蓄電池の出力結果であ る。 $\mathrm{PQ}$ 出力は, 「然料電池の $\mathrm{PQ}$ 出力と負荷の $\mathrm{PQ}$ 需要の 差分」という条件を満たしている。また，Fig. 20(b) にお いて，5[s] で蓄電池の作り出す周波数は 49.9967 [Hz] であ る。この周波数を P-f 特性曲線に代入すると, 蓄電池出力は $3.3[\mathrm{~kW}]$ となり，これはシミュレーション結果の Fig. 20(a) と一致することが分かる。Fig. 20(c), (d) は燃料電池 1 の 出力結果である。Fig. 20(d) において, 5 [s] で然料電池の PLL が検出する周波数は $49.9965[\mathrm{~Hz}]$ である。この周波数 を P-f 特性曲線に代入すると, 燃料電池出力は $1.74[\mathrm{~kW}]$ と なり,これはシミュレーション結果の Fig. 20(c) と一致す ることが分かる。

〈4·2〉 3 階建て集合住宅のシミュレーション＼cjkstart蓄電池 1 台, 燃料電池 3 台, 負荷 3 台のマイクログリッドを考え る。これは，各階に 10 戸と燃料電池が 1 台，屋上には太

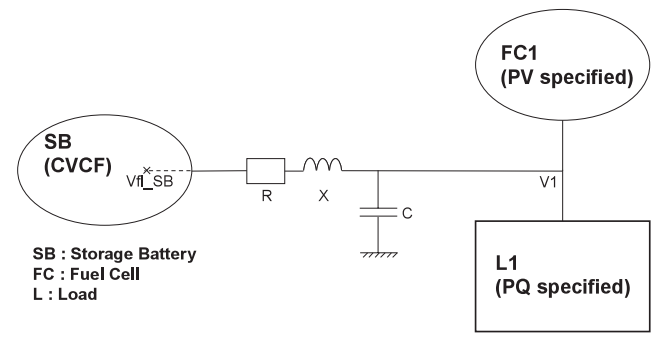

Fig. 18. Model system $(\mathrm{SB} \times 1, \mathrm{FC} \times 1, \mathrm{~L} \times 1)$.

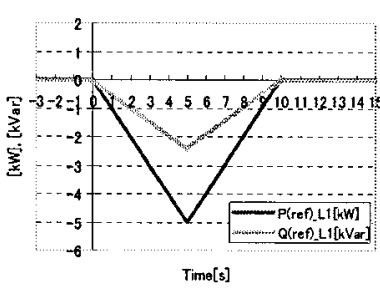

(a) PQ reference of load No.1

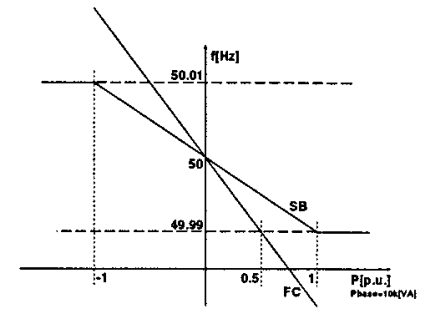

(b) P-f characteristic curves of storage battery and fuel cell
Fig. 19. PQ reference and P-f characteristic curve. 


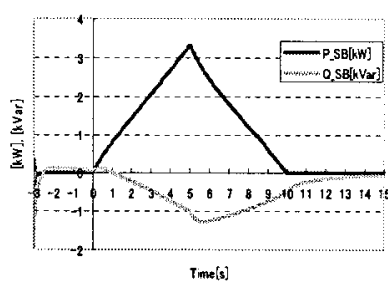

(a) PQ output of storage battery

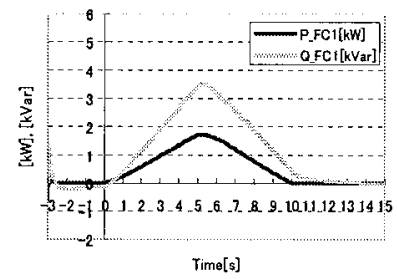

(c) PQ output of fuel cell No.1

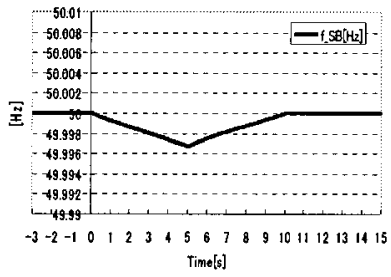

(b) Frequency output of storage battery

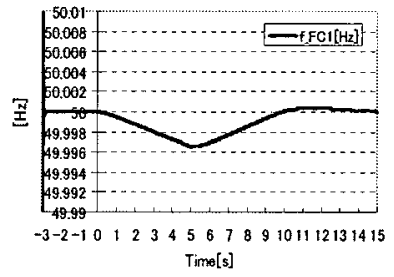

(d) Frequency output from PLL of fuel cell No.1

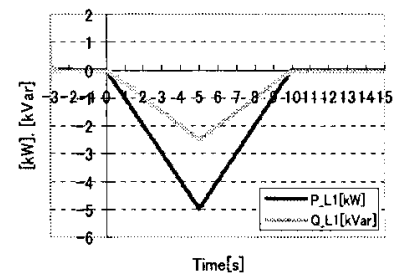

(e) PQ output of load No.1

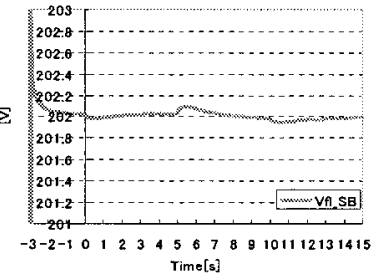

(f-1) Vfl_SB

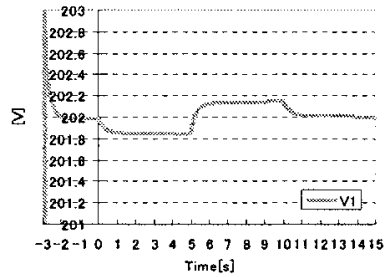

(f-2) V1
Fig. 20. Output results.

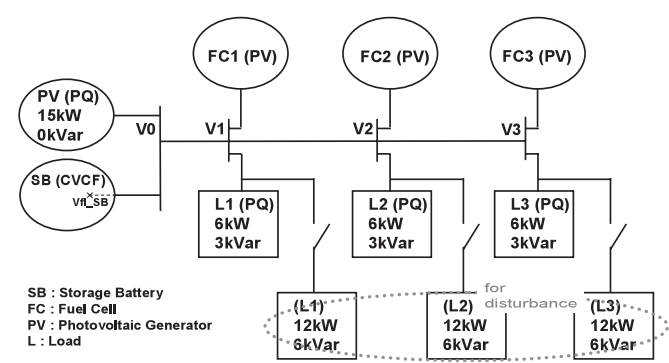

Fig. 21. Model system $(\mathrm{SB} \times 1, \mathrm{PV} \times 1, \mathrm{FC} \times 3, \mathrm{~L} \times 3)$.

陽光発電と蓄電池を有する 3 階建てのマンションを想定し ている。なお，シミュレーション時刻は 12 時を想定する。 この時間に，太陽光発電による系統への影響が最大となる からである。

（1）条件 Fig. 21 にモデル系統を示す。各分散型電 源間の配電線の長さは $100 \mathrm{~m}$ で，定数は Fig. 18 と同じで ある。

Fig. 22(a) に太陽光発電の PQ 指令を, Fig. 22(b) に負荷 の $\mathrm{PQ}$ 指令を示す。なお， $-10 \sim 0[\mathrm{~s}]$ はシミュレータの立 ち上げ期間である。蓄電池と燃料電池は，〈4·1〉節と同様

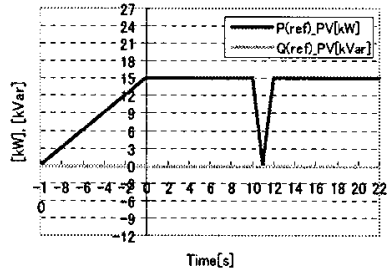

(a) PQ reference of photovoltaic generation

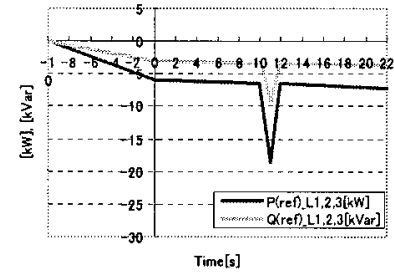

(b) PQ reference of load No.1,2,3
Fig. 22. PQ reference.

の P-f 特性曲線を用いて自律分散型の需給制御を行う。

太陽光発電は， $0[\mathrm{~s}]$ において，P_PV = $15[\mathrm{~kW}]$ とした が，この点が 12 時の太陽光発電出力であり，10〜12 [s]に 短期の変動が発生する。各負荷は, $0[\mathrm{~s}]$ において, P_L = $-6[\mathrm{~kW}]$ としたが，この点が長期の負荷変動の初期值であ る。その後，20秒間で 20\%の負荷増加をし，10１2 [s]に 短期の変動が発生するものとする。

(2) 出力結果 Fig. 23 に出力結果を示す。

（3）考察 Fig. 23(a), (b) は蓄電池の出力結果であ る。評価パラメータとしての必要蓄電池 $\mathrm{kW}$ 容量は, 11 [s] における 32.14 [kW] となった。Fig. 23(d)〜 (i) は燃料電池 $1 ， 2 ， 3$ の出力結果であり, 中期の負荷変動, $10 \sim 12[\mathrm{~s}]$ に おける短期の負荷変動の両者に追従できていることが分か る。これは, P-f 特性曲線による制御のレスポンスが早い ためである。しかし, 現在の出力変動率に問題がある燃料 電池を考慮すると, 実用化には時間を要するものと思われ る。また，11[s]における燃料電池の PLL が検出する周波 数変動が蓄電池の作り出す周波数変動に比べて鋭いのは, Fig. 23(k) に示すようなノード電圧の影響を受けて燃料電池 のPLL が周波数変動を作り出していることに起因する。

Fig. 23(k) は各ノードの電圧である。蓄電池制御端子の変 動が最も小さく, この点より離れるに従って, 電圧の変動 は大きくなることが見てとれる。

\section{5. 自律分散型需給制御における周波数制御}

本論文では, 分散型電源の出力制御のための手段として, 蓄電池の作り出す自営線の周波数を用いる手法を提案した。 蓄電池を CVCF 運転させ, 負荷の需要変動に応じて変動す る蓄電池出力に対応させて周波数を微小に変動させること で，マイクログリッド全体に分布するインバータを用いた 制御可能な分散型電源に周波数という形で, 負荷の需要変 動情報を送っている。例えば, Fig. 23(b)，(e), (g), (i) を見 ても分かる通り, 分散型電源の PLL が検出する周波数は, 蓄電池の作り出す基準周波数との間に偏差を持っている。

ここで, 周波数が負荷の需要変動伝達手段としての役目を 果たした後の状態を考えると, 周波数は基準周波数 $(50[\mathrm{~Hz}])$ に戻ることが望ましい。Fig. 24 にシステムの階層制御の様 子を示す。需給制御システムの上位に「周波数制御システ ム」を加えたものである。

$\langle\mathbf{5} \cdot \mathbf{1}\rangle$ 周波数制御の概要 Fig. 18 の蓄電池 1 台, 燃 


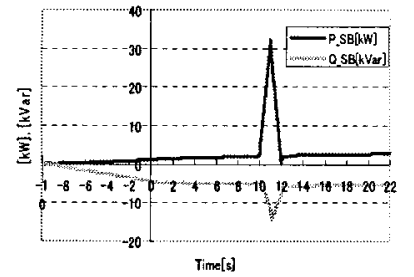

(a) PQ output of storage battery

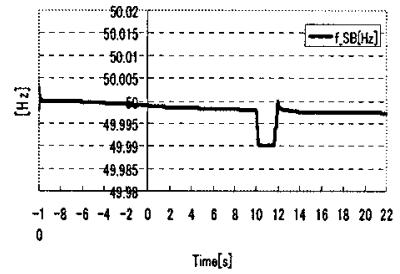

(b) Frequency output of storage battery

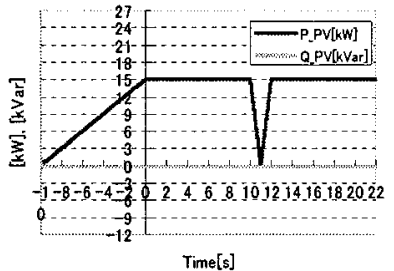

(c) PQ output of photovoltaic generation

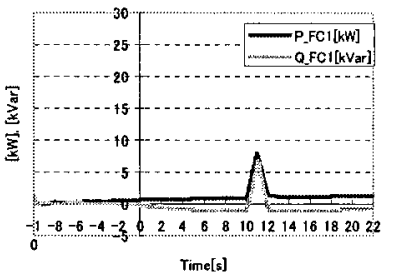

(d) PQ output of fuel cell No.1

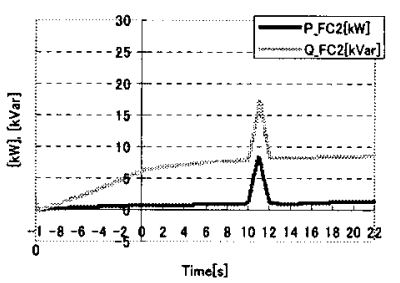

(f) PQ output of fuel cell No.2

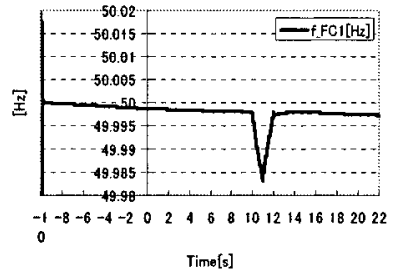

(e) Frequency output from PLL of fuel cell No.1

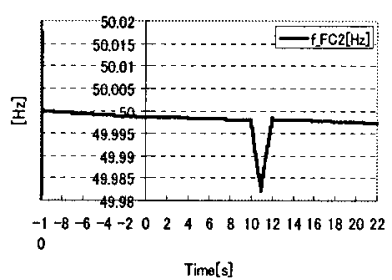

(g) Frequency output from PLL of fue cell No. 2

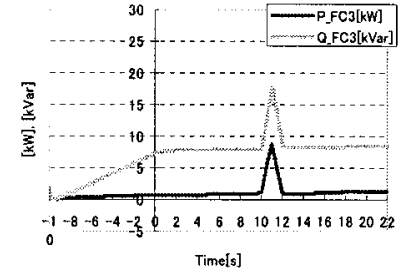

(h) PQ output of fuel cell No.3

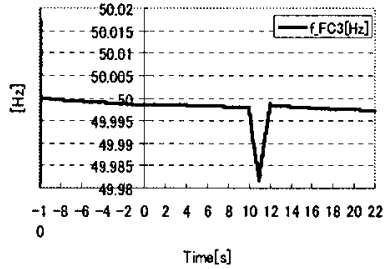

(i) Frequency output from PLL of fuel cell No.3
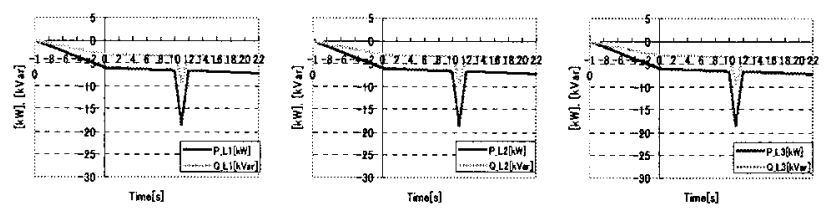

(j) PQ output of load No.1,2,3
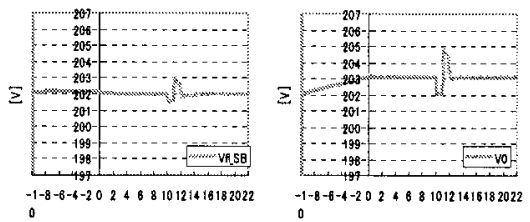

Timels]
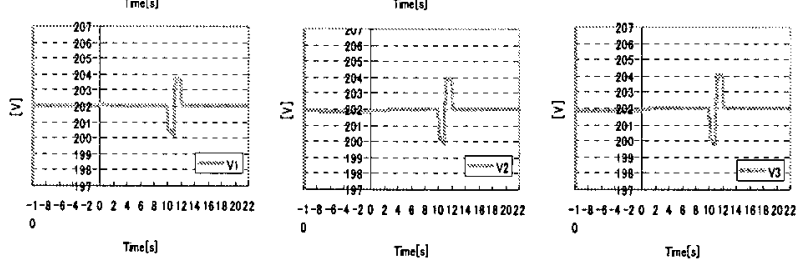

(k) Voltage

Fig. 23. Output results.

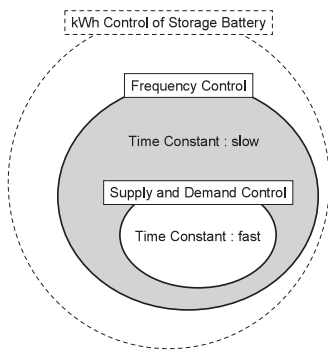

Fig. 24. Hierarchical control of system.

料電池 1 台，負荷 1 台の簡単なモデル系統を用いて，特性 曲線による自律分散型の需給制御時の周波数制御を考える。

周波数を基準周波数に戻すために，燃料電池の P-f 特性 曲線をオンラインで平行移動させることを考える。この制 御の概要を Fig. 25 に示す。

初期状態を直線 $\mathrm{FC}(\mathrm{A})$ とし, 負荷出力が $\mathrm{P} L 1=-15[\mathrm{~kW}]$ の場合を考える。負荷需要は蓄電池出力と燃料電池出力の和 であるため, 周波数は $49.99[\mathrm{~Hz}]$ となり, P_SB $=10[\mathrm{~kW}]$,

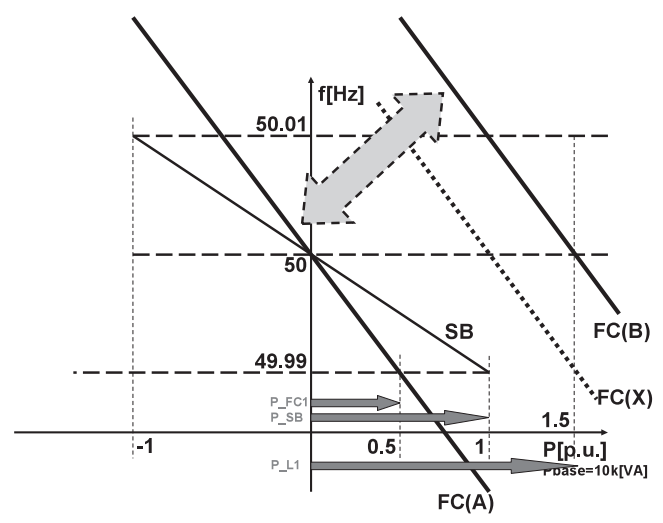

Fig. 25. Frequency control.

P_FC1 = 5 [kW] の分担となる。

ここで, 燃料電池の P-f 特性曲線を直線 FC(A) から直線 $\mathrm{FC}(\mathrm{B})$ へと平行移動させる。すると, 周波数は $50[\mathrm{~Hz}]$ と なり, P_SB $=0[\mathrm{~kW}], \mathrm{P} \_\mathrm{FC} 1=15[\mathrm{~kW}]$ の分担となる。こ れは，常に蓄電池の出力を燃料電池に負担させようとする 制御であり，定常状態では系統周波数が $50[\mathrm{~Hz}]$ に維持さ 


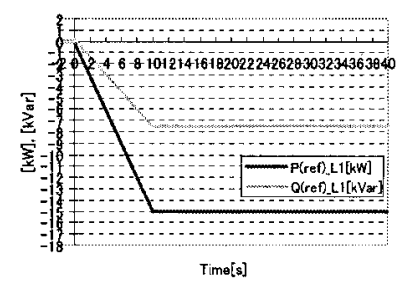

Fig. 26. PQ reference of load No.1.

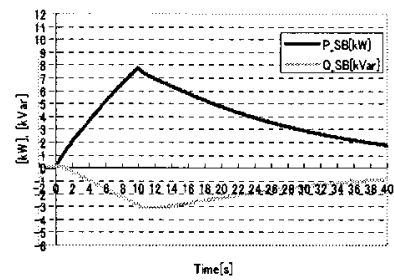

(a) PQ output of storage battery

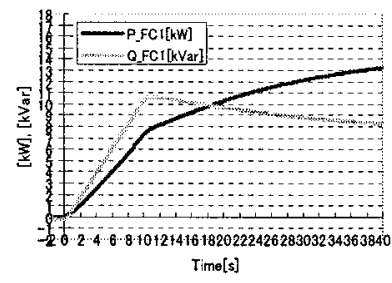

(c) PQ output of fuel cell No.1

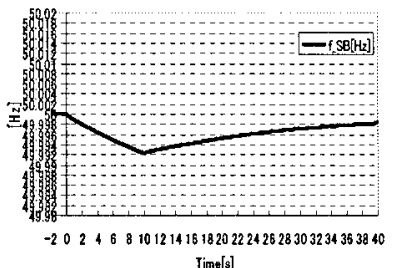

(b) Frequency output of storage battery

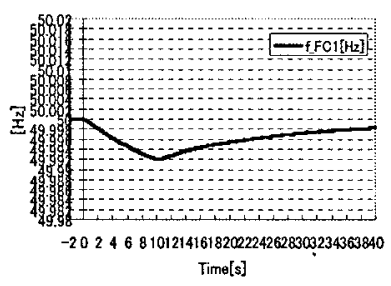

(d) Frequency output from PLL of fuel cell No.1

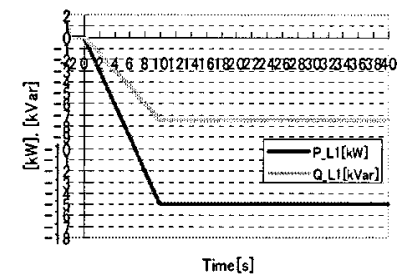

(j) PQ output of load No.1

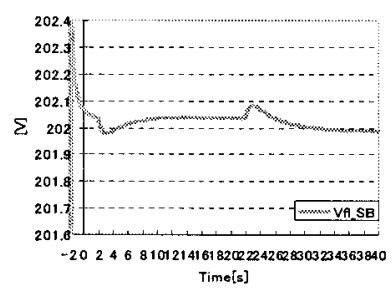

(f-1) Vfl_SB

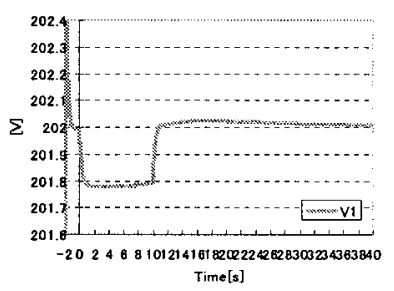

(f-2) V1
Fig. 27. Output results.

れることを意味する。この制御を負荷需要の変動に合わせ て時々刻々と行う。

ところで，本提案手法では，燃料電池システムは蓄電池 システムの P-f 特性曲線デー夕を把握している必要がある。 この蓄電池の P-f 特性曲線デー夕と燃料電池自身が PLL で 検出する周波数より, 燃料電池システムは, 通信網なしで オンラインで蓄電池の出力を把握し得る。

〈5·2〉 シミュレーション Fig. 26 に負荷 1 の PQ 指 令を示す。なお，シミュレータの $-2 \sim 0[\mathrm{~s}]$ は立ち上げ期 間である。
Fig. 27 に出力結果を示す。

Fig. 27(a), (b) は蓄電池の出力結果である。周波数制御シ ステムを考慮しない場合, 10 [s]において, P_SB = 10 [kW], f_SB $=49.99[\mathrm{~Hz}]$ となる。一方，周波数制御システムを考 慮した場合，10[s]に扔いて，P_SB = $7.78[\mathrm{~kW}]$, f_SB = $49.992[\mathrm{~Hz}]$ となり, 10 [s] 以降も, P_SB はゼロへと収束 し，f_SB は $50[\mathrm{~Hz}]$ へと収束していくのが分かる。

Fig. 27(c)，(d) は燃料電池 1 の出力結果である。周波数 制御システムを考慮しない場合，10[s]に扔いて，P_FC1 = $5[\mathrm{~kW}], \mathrm{f} \_\mathrm{FC} 1=49.99[\mathrm{~Hz}]$ となる。一方, 周波数制御シス テムを考慮した場合, $10[\mathrm{~s}]$ に扔いて, P_FC1 = $7.25[\mathrm{~kW}]$, f_FC1 = $49.992[\mathrm{~Hz}]$ となり, 10 [s] 以降も,P_FC1 は $15[\mathrm{~kW}]$ へと収束し, f_FC1 は $50[\mathrm{~Hz}]$ へと収束していくのが分かる。

\section{6. おわりに}

本研究では, 分散型電源を多数台接続可能な三相瞬時値 ディジタルシミュレーション技術を確立すると同時に，マ イクログリッドに抢けるインバータ電源群を用いた需給制 御方式を提案し，有効性の検証を行った。

交流の自営線に接続されたインバー夕を用いた燃料電池 群，蓄電池，負荷の需給バランスをとる制御方式として，自 営線の周波数を情報伝達手段とする自律分散型制御方式を 提案した。本提案方式は, 負荷の需要変動を, まずCVCF 制御の蓄電池が出力変動として検出し, P-f 特性曲線に基づ いて周波数を変動させ，それを燃料電池の PLL が検出し， P-f 特性曲線に基づいて発電出力を変動させるものであっ た。また，その燃料電池の P-f 特性曲線を平行移動させる ことによって，周波数を基準周波数に維持する制御も行っ ており, 三相瞬時值シミュレーションにより本提案手法の 有効性を確認した。

今後は，シミュレータをより現実の動作に近づける必要 がある。太陽光発電の出力変動や負荷の出力変動に実測し たものを用い, 蓄電池, 及び燃料電池などの各分散型電源 に固有の特性を考慮することが望まれる。また，長時間領 域において, 蓄電池の貯蔵容量 $[\mathrm{kWh}]$ の制御を考慮する必 要がある。

(平成 18 年 2 月 27 日受付, 平成 18 年 7 月 12 日再受付)

\section{文献}

（1）合田忠弘 - 田熊良行 - 泉井良夫 - 小島康弘 - 竹内英次郎 - 高坂 幹： マイクログリッドー分散型電源と電カネットワークの共生のために, 日本電気協会新聞社 (2004)

（2）「平成 11 年度 系統連系円滑化実証試験調査一シミュレーションに よる実証試験」, NED-NP-9919 (200-3)

(3) M. Yamaguchi, A. Iga, K. Ishihara, D. Wada, K. Yoshii, and O. Sueda: "Study for Merit of Battery Combined Photovoltaic Generation System for Residential House", IEEJ Trans. PE, Vol.123, No.3, pp.402-411 (2003-3) (in Japanese)

山口雅英·伊賀 淳 ·石原 薰·和田大志郎·吉井清明·末田 統 : 「住宅用太陽光発電・蓄電池組み合わせシステムのメリットに関す る研究」, 電学論 B, 123, 3, pp.402-411 (2003-3)

(4) 「平成 16 年度電力系統関連設備形成等調査一分散型電源を系統へ連 系した場合の系統安定に関する調査一報告書」, エネルギー総合工学 研究所 (2005-3) 
( 5 ) K. Okuyama, T. Kato, K, Wu, Y. Suzuoki, and T. Funabashi: "Load Leveling in Distribution System by Autonomous Control of Distributed Generators", IEEJ Trans. PE, Vol.123, No.3, pp.304-314 (2003-3) (in Japanese) 奥山賢治・加藤丈佳 · 呉 カイ・鈴置保雄・船橋俊久：「分散電源の 自律制御による需要地系統の負荷平準化」, 電学論, 123, 3, pp.304-314 (2003-3)

志 岐明 (学生員) 1981 年 1 月 1 日生。 2004 年 3 月東京 工業大学工学部電気工学科卒業。同年 4 月東京大学大学院工学系研究 科修士課程電気工学専攻入学。現在に至る。

横 山 明 彦 (正員) 1956 年 10 月 9 日生。1979 年 3 月東京

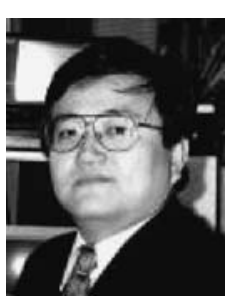
大学工学部電気工学科卒業。1984 年 3 月同大学 大学院工学系研究科電気工学専門課程博士課程修 了。工学博士。1984 年 4 月同大学工学部電気工学 科助手。1985 年同講師。1989 年同助教授。1995 年同大学大学院工学系研究科電気工学専攻に配置 換。2000 年 9 月同教授。現在に至る。主に電力 システム工学 (電力システムの解析·計画・運用· 制御）の研究に従事。電気学会, 計測自動制御学会, 日本応用数理学 会, IEEE，CIGRE 会員。

馬 場 旬 平 (正員) 1973 年 6 月 3 日生。1996 年 3 月東京大

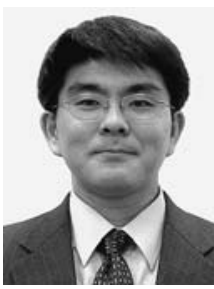
学工学部電気工学科卒業。2001 年 3 月同大学大 学院工学系研究科電気工学専攻博士課程修了。同 年 4 東京理科大学理工学部電気工学科助手。2003 年 4 月東京大学大学院新領域創成科学研究科先端 エネルギー工学専攻助手。2005 年 4 月東京大学 大学院工学系研究科電気工学専攻講師。2006 年 4 月同助教授。現在に至る。主に超電導電力応用機 器，パワーエレクトロニクス電力応用の研究に従事。電気学会, IEEE, 低温工学協会会員。
高 野 富 裕 （正員） 1964 年 8 月 26 日生。1989 年 3 月京都

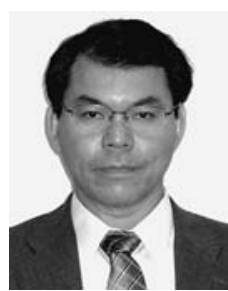
大学卒業。1991 年 3 月同大学大学院工学研究科 精密工学専攻修士課程修了。同年 4 月三菱電機 （株）入社。先端技術総合研究所に勤務し，電力 系統の運用・制御・保護，分散型電源の制御やマ イクログリッドの研究開発に従事。計測自動制御 学会, CIGRE 会員。

合 田 忠 弘 （正員） 1947 年 8 月 10 日生。1973 年 3 月大阪

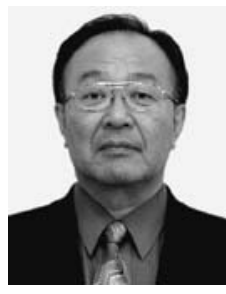
大学大学院工学研究科修士課程修了。同年 4 月 三菱電機（株）入社。電力系統の保護制御システ ムの開発・製造，パワーエレクトロニクスや電力 自由化・規制緩和関連のシステム開発，系統解析 シミュレータやマイクログリッドの開発に従事。 2006 年 3 月三菱電機（株）を退職。現在，九州大 学教授。工学博士。1991 年電気学会論文賞受賞。

泉 井 良夫（上級会員） 1959 年 2 月 2 日生。1 986 年 3 月東

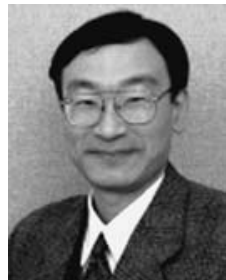
京大学大学院工学系研究科電気工学専攻博士課程 修了。同年 4 月三菱電機（株）入社。先端技術総 合研究所にて電力系統システムの計画・運用に関 する研究開発に従事。工学博士。2005 年電気学会 進歩賞受賞, 2006 年電気学会論文賞受賞。IEEE, 電子情報通信学会，計測自動制御学会会員。 